\title{
Teaching Materials Development and Meeting the Needs of the Subject: A Sample Application
}

\author{
Abdullah Aydın ${ }^{1} \&$ Cahit Aytekin ${ }^{2}$ \\ ${ }^{1}$ Department of Science Education, Faculty of Education, Ahi Evran University, Kırşehir, Turkey \\ ${ }^{2}$ Department of Mathematics Education, Faculty of Education, Ahi Evran University, Kırşehir, Turkey \\ Correspondence: Abdullah Aydın, Department of Science Education, Faculty of Education, Ahi Evran University, \\ Kırşehir, Turkey. Tel: 90-505-487-4471. E-mail: aaydinch@gmail.com
}

Received: September 27, 2017

doi:10.5539/ies.v11n8p27

\author{
Accepted: December 1, 2017 \\ Online Published: July 6, 2018 \\ URL: https://doi.org/10.5539/ies.v11n8p27
}

\begin{abstract}
It has been determined that the drawings, photographs and pictures related to the subject of the continuity of the tangent function on page 68 of the Ministry of National Education's twelfth-grade mathematics textbook contradict principles 1, 7 and 10 of Yanpar's (2007) teaching material development principles. According to these principles, teaching materials should: i) be simple, plain, and understandable, ii) reflect real life as much as possible, and iii) be easy to develop or revise, if necessary. This study aims to develop a portable tangent bridge model to meet the needs of the subject of the continuity of the tangent function. With this aim: i) teaching with the analogies model in the design of the teaching material, ii) "this is my project" format in the development and iii) Yanpar's (2007) principles were considered. The design of the model lasted 14 weeks. At the end of the study, a portable tangent bridge model from waste products was designed and developed. This model is thought to contribute to the teaching effectiveness of teachers (Shulman, 1987) with content knowledge alongside with pedagogical knowledge (Shulman, 1986). With this contribution, the needs of the subject as described by Taba (1962) and Tyler (1949) will be met. This model will also serve as an example of meeting the needs of the subjects of knowledge and its product, technology, as highlighted by Cahit Arf (Terzioğlu \&Yılmaz, 2006).
\end{abstract}

Keywords: teaching material development, meeting the needs of the subject, sample application, science education, mathematics education

\section{Introduction}

"No period in human history has been full of scientific and technological discoveries as the last half of this century, and this dizzying progress has caused a transition from an industrial society to an information society" (Bayram, Patl1, \& Savc1, 1998b, p. 31). Within this period, it is of importance to encourage especially self-learning and thinking (Küçük, Yetim, Saka, \& Genel, 2002). In self-learning, "the role of students' prior knowledge in meaningful and correct learning cannot be ignored" (Demircioğlu, Vural, \& Demircioğlu, 2013, p. 66).

This information contributes to the correct construction of mental pathways (Winston, 2003). The mental pathways are found in the brain and "the brain is centre of the information universe" (Sturges, 2014, p. 3). This center is plays a central role in mental activity and controlling bodily (Winston, 2003). "We can learn from neuro-imaging explains virtually all mental phenomena" (Sturges, 2014, p. 9). "System One (right hemisphere) mental is active in our relationship to information" (Sturges, 2014, p. 13).

According to Peyami Safa, this contribution is dependent on experience, not the age (Meşhur Sözler, 2013). Scientists with a lot of experiences such as Galileo, Newton, and Borh have walked on these pathways and their ideas have changed the world (Winston, 2003). The ideas that change the world are "not spoken language, but mathematical thoughts" (Hardy, 1994, p. 61). Learning and teaching mathematical thoughts cannot be understood without considering the solution of verbal problems (Gasco, Villarroel, \& Zuazagoitia, 2014).

Since the theories constructed the axiomatic thought, namely the basic assumptions, are falsifiable, mistakes can be recognized, and a step forward can be taken (Altunkaya, 2013). For instance, if the boundaries of Newton's physics were not recognized, Einstein' physics could not be reached. According to Einstein, the source of this thought is "mind (intelligence)" (Saygil1, 2008, p. 31). "The mathematical thought" comes from this source (Hardy, 1994, p. 61). According to Robert Stermberg (1981), intelligence has three components: "analytic, creative 
and practical thinking skills" (Sayg1l1, 2008, p. 31). That is to say, it is in the order of perceiving different solutions, understanding relations and applying concepts to daily life. Furthermore, "this service is done as the simplest and most distant among all science and arts" (Hardy, 1994, p. 109). In addition, the development of these thoughts in accordance with their internal logics arouses the idea that they are the central element in the development of modern science (Westfall, 1994). According to Einstein, science is the effort of reconciliation between sensory data (perceptions) lacking any sort of organization and reasonably regular thinking (Bayrakçeken \& Çelik, 2007).

The thoughts that arose the idea that they are the central element in the development of science (Westfall, 1994) are placed in the mind with thoughts according to Socrates and Einstein (Yıldırım, 2009; Güran, 2011), which is the center of the objects according to Kant (Yalçın, 2014), and they are seen through thoughts according to Hegel (Yalçın, 2014). The thoughts are transferred to the mind with "analogies that are likened to the wings of the thought" (Aydın, 2012, p. 159). "Analogies are the bridges between the known and unknown" (Morgil, Erdem \& Yllmaz, 2003, p. 252). The constructionist theory forms the ground of these bridges (Pittman, 1999).

According to this theory, students' conceptual knowledge be developed and increased by the analogies they construct and thus, their problem-solving skills will be developed (Kesercioğlu, Yılmaz, Huyugüzel Çavaş \& Çavaş, 2004). These skills can be acquired in a constructionist classroom.

In a constructionist classroom, "learning contains thinking, and learning is achieved through reflection" (Köseoğlu \& Tümay, 2013, p. 32). Thus, "meaningful learning is achieved by establishing connections between previous and new knowledge" (Köseoğlu \& Tümay, 2013, p. 34).

"Science teachers should use updated methods and techniques in order to make the learning more meaningful by using the scientific language in a comfortable way to make subjects and concepts more understandable" (Kesercioğlu et al., 2004, p. 36). Analogies as a new teaching method can be used in constructing bridges between previous and new knowledge (Kesercioğlu et al., 2004, p. 36).

In recent years as well as in the periods of Maxwell, Rutherford and Einstein (Curtis \&Reigeluth, 1984), analogies have been considered one of the most important elements in establishing these relationships in the learning and teaching of science (Brown, 1993; Clement, 1993; Dagher, 1995; Duit, 1991; Thiele \& Treagust, 1994; Vosniadou, 1989).

"Analogies are especially effective in teaching physics, chemistry and biology concepts that are not related to students' experiences" (Kesercioğlu et al., 2004, p. 37). As a result of their use, "strong bridges between students' knowledge from experiences and new knowledge are established" (Kesercioğlu et al., 2004, p. 37). These bridges:

- increase students' interest, curiosity, and motivation (Keller, 1983),

- $\quad$ support conceptual change (Dagher, 1994)

- $\quad$ serve as effective tools for building relationships between concepts (Stepich \& Newby, 1988).

If these bridges are not established, "students cannot apply their knowledge outside of school, but applying knowledge outside of the school is a worthy aim" (Köseoğlu \& Tümay, 2013, p. 34). Analogies provide a bridge between previous and new knowledge that makes it possible (Glynn \& Takahashi, 1998). Analogies can be constructed as:

- "a direct metaphor between two things as well as stories and models" (Köseoğlu \& Tümay, 2013, p. 118)

- “description” (Kesercioğlu et al., 2004, p. 36)

Analogies are used for knowledge that is well-known and located in long-term memory that can be related to new knowledge (Lawson, 1993). Analogies are like using old and durable knowledge to cast a fishing line to new knowledge.

In order to realize constructionist learning, "first of all students' thoughts should be revealed" (Köseoğlu \& Tümay, 2013, p. 143). The development of thoughts, which arouse the idea that they are the central element in the development of modern science, in accordance with their internal logics should be provided (Westfall, 1994).

If this development is not provided, universities and industry will continue to see each other through the lens of frosted glass. In other words, the thoughts that are the central elements in the development of modern science will not serve industry and thus society. In fact, "the purpose of technology making changes in the natural world is to meet the desires and needs of people" (Milli Eğitim Bakanlığı [MEB], 2004, p. 6). The purpose of science, on the other hand, is "to try to understand and explain the natural world" (MEB, 2004, p. 6). Realizing the purpose of science, the need of the subject, and realizing of technology will meet the needs of society. "Learners' needs should be met by translating the subject in a language that students can understand without any misconception" (Shulman, 
1986, 1987). Teaching material development is significant in meeting learners' needs (Aydın, 2013b).

Providing this need depends on the development of "permanent mathematical thoughts" (Hardy, 1994, p. 61). This development can be achieved by putting thoughts in "analogies likened to the wings of thought" (Aydın, 2012, p. 159). This makes it easy to make learning new knowledge more meaningful, make the knowledge learned more permanent, to reason with the new knowledge and to cause conceptual change (Glynn \& Takahashi, 1998). In other words, it makes it possible to see knowledge through thought according to Hegel (Yalçı, 2014), which is placed with thought according to Socrates and Einstein (Yıldırım, 2009; Güran, 2011), in the mind that is the center of the objects according to Kant (Yalçın, 2014). In this way, the needs of the subject indicated by Taba (1962) and Tyler (1949) will be met. Projects, drama and animation activities are important in meeting these needs. Among them, projects bring together students' knowledge and skills (Fook \& Sidhu, 2010).

In a study of animation, it was revealed that teaching trigonometry with animation activities increases its memorability (Örnek, 2007). "The use of drama and animation activities in mathematics lessons contributes to students' development cognitively and socially as well as physically and mentally" (Örnek, 2007, p. 76).

Another study indicated the importance of the chemical coding system that corresponds to the symbolic dimension in chemistry, which has a three-dimensional knowledge structure: micro, macro and symbolic (Sarıtaş \& Tufan, 2012). Furthermore, it is important to do this coding correctly. Thomas Aquinas describes correctness as "the match between what is mental and objective" (Baç, 2007, p. 577). According to this match, Gödel claimed "everything that is true cannot be proved" (Say, 2005, p. 67). According to Tolman (1922), a goal-oriented behavior is important in this match (Yeniçeri, 2003). Modern behaviorism is predominantly physiological. Latent learning is achieved when this predominance is ignored according to Viney and King (1998) (Yeniçeri, 2003).

Tolman proposes that latent learning occurs in a way like mice's spatial learning and their development of cognitive maps of mazes (Tolman, 1948). This corresponds to Thomas Aquinas's definition of correct. In other words, what is mental and objective match in mice? It is important to develop materials to meet the needs of the subject in order to provide this match.

\subsection{Conceptual Framework}

One of the main domains of philosophy, epistemology, by its traditional definition, "intends to describe the philosophical story behind the functions of acquiring ordinary information that people perform naturally and regularly" (Baç, 2007, p. 567). In this story, propositional truth is a very essential and critical concept; however, it contains philosophically complex and controversial aspects because it involves distinct fields such as being, knowledge, meaning and language (Baç, 2007). While this concept is defined by Aristotle as the existence of existing and the nonexistence of nonexisting, it was defined as reconciliation between the mental and the objective by Thomas Aquinas as understood today (Baç, 2007). The thesis that proposes this reconciliation takes place between a proposition and a phenomenon has dominated the literature (Baç, 2007). This reconciliation, "according to Plato, access to knowledge occurs by understanding universals through reasoning" (Baç, 2007, p. 570). The bricks of perception are important in the construction of our knowledge building according to Locke, Berkeley and Hume (Baç, 2007). "People try to make sense of these bricks" (Demirel, 2011, p. 37). While according to Gestaltism, "the world is perceived as a whole" (Demirel, 2011, p. 37), "according to Rogers, reality depends on students' perceptions" (Demirel, 2011, p. 39).

Perceptions are semiotic and transmitted by symbols (Güçlü, 2013). In the chemical coding system, each structure from element symbols to equations are symbols that lose their meaning if there is not an interpretation based on semiotic consensus (Sarıtaş \& Tufan, 2012). In fact, it is learned through symbols (Güçlü, 2013). It is important to connect these symbols with "permanent mathematical thought" (Hardy, 1994, p. 61) because "mathematical thoughts are permanent, unlike spoken language" (Hardy, 1994, p. 61). It has been determined that reasoning skills greatly affect students' achievement (Bayram, Sökmen, \& Gürdal, 1999).

Animation activities have been determined to enhance the permanence of these thoughts (Örnek, 2007). "Design is the act of mental animation" (Kaya, Tüfekçi, \& Bilasa, 2010, p. 20). This animation is a learning method (Winston, 2003). High-level mental processes - such as detecting differences, imagining, questioning, critical thinking and reasoning - have a significant role in designing animation (MEB, 2006, pp. 3-4). Among them, "critical thinking comes to the forefront in terms of making analogies" [Rico, 1976, p. 18-23]; as cited in (Beydoğan, 2011, p. 9). In other words, students need to connect the new knowledge with their previous knowledge in order to meet the needs of the subject, according to Ertürk "to explain the structure and process of the subject" (Özçelik, 1988, p. 31), which is to say, "to realize meaningful learning" (Köseoğlu \& Tümay, 2013, p. 117). It is important to use analogies effectively. The fact that Maxwell, Rutherford and Einstein made problems better understood by using analogies highlights this importance (Curtis \& Reigeluth, 1984). Today, studies have been conducted towards the 
teaching method stress of these scientists. That is to say, many studies indicated a significant increase in students' achievement in experimental group in which analogies were used (Atav, Erdem, Yllmaz, \& Gücüm, 2004; Bilgin \& Geban, 2001; Saygill, 2008, p. 63).

In a study on the subject of trigonometry from an eighth-grade mathematics curriculum besides the teaching with analogies model proposal (Glynn, Duit, \& Thiele, 1995), the following suggestions were proposed:

- "Materials, scenarios, and educational tools which are appropriate for the animation method should be designed and made available to teachers and educators,"

- "Studies of the effect of using the animation method in education on students' attitudes towards mathematics, achievement and creativity at all classroom levels should be conducted" (Örnek, 2007, p. 77).

In the design of curricula (Schnackenberg \& Still III, 2014), it is important to identify the learners' learning roles and the thoughts behind these roles (Aydin, 2013a) as well as the learning understandings and learning methods (Aydın, 2012). In addition, it is necessary to increase and extend the permanence of this thought. To do so, mathematics that is the mind itself according to Einstein (King, 2003), "namely permanent mathematical thoughts" comes to the forefront (Hardy, 1994, p. 61). In order to materialize these thoughts, analogies have been used by Maxwell, Rutherford and Einstein to make problems better understood (Curtis \& Reigeluth, 1984). Teaching with the analogies model has been proposed by Glynn et al. (1995) who demonstrate how to use analogies effectively in teaching.

A teaching material from waste products has not been designed or developed in order to extend this effective use and to meet the needs of the subject indicated by Taba (1962) and Tyler (1949). This study is thought to contribute to the literature and be significant for all these reasons.

\subsection{Problem Statement}

Ronald Reagan's sentence, "Life is one grand sweet song, so start the music," (My Yoga Online, 2014) implies that life begins with art. John Christian likened life to "the art of drawing pictures without using an eraser" (Forum Memurlar Net, 2014). The lines of this art are learned "at the school that is life itself" according to Cahtelain (Kosmoss.net, 2014). It is understood that these lines are the thought of Pablo Picasso's saying, "I paint objects as I think them, not as I see them" (Ressamlar, 2014). This idea is expressed as imagination by Marcus Aurelius who said, "A person's life is dyed with the color of his imagination" (Bilge Sözleri, 2014). Tolman describes it as performance that transforms line/thoughts/imagination into observable behavior when necessary (Yiğit, 2013). According to Hardy, "permanent mathematical thoughts" (Hardy, 1994, p. 61) are important in this performance. Perceptions are the fertilizer of these thoughts. A person lives on his own with an unreal perceptional map (Demirel, 2011). "According to Rogers, reality depends on students' perceptions" (Demirel, 2011, p. 39), and "they try to make sense of the field with their perceptions" (Demirel, 2011, p. 37). According to Locke, Berkeley and Hume, this meaning constitutes the bricks of perception, and with these bricks the building of knowledge is constructed (Baç, 2007). The mental animation is important in this construction, namely, meeting the needs of the subject (Winston, 2003). Teaching material development to meet the needs of the subject is effective in learning this building (Aydın, 2013b). In order to identify this activity as performance according to Tolman (Yiğit, 2013), it is necessary to meet the needs of the subject. The mathematical thought described by Hardy (1994) is of importance in meeting these needs. Is thought expressed by Hardy (1994) effective in teaching material development to meet the needs of the subject? This research sought an answer to this question in particular.

\subsection{The Aim of the Study}

It is difficult to understand and interpret theoretical data that is not based on experimentation (Genç, Genel, \& Küçük, 2001). Therefore, conceptual learning has great importance in secondary education (Küçük \& Saka, 2001). This study aims to develop teaching with the analogies method (Glynn et al., 1995), namely, a Portable Tangent Bridge Model to meet the needs of the concept/subject, as described by Taba (1962) and Tyler (1949), of the continuity of the tangent function on page 68 of the twelfth grade mathematics textbook (MEB, 2012a, p. 68).

- This study aimed to recycle of waste products such as styrofoam, battery, thin cable, small lamps, and silicone, which cause environmental pollution.

\subsection{Research Questions}

The study sought to answer the question, are the drawings, photographs and pictures related to the concept/subject of the continuity of the tangent function on page 68 of the twelfth grade mathematics textbook in accordance with principles 1, 7 and 10 of Yanpar's (2007, p. 155) material development principles? These principles indicate that a teaching material should: 
- be simple, plain and understandable,

- reflect real life as much as possible,

- be easy to develop or revise, if necessary.

In other words, a teaching material should provide a meaningful and comprehensive presentation of the subject, which is to say, it should meet the needs of the subject described by Taba (1962) and Tyler (1949).

\section{Method}

"Well-trained teacher candidates should be taught the best method to transmit knowledge" (Bayram, Sökmen \& Savc1, 1997a: 98) or "teaching styles" (Bayram, Patlı \& Savcı, 1998a: 21) at the same time. This transmission of knowledge involves:

- "visualizing concepts" (Bayram et al., 1998a, p. 29),

- “students' true learning and use of concepts" (Bayram, Sökmen, \& Savc1, 1997b, p. 79).

Models are important for this. They make it easier for the seemingly complex event(s) to be understood by people (Paton, 1996). Teaching materials are important to this facilitation process because, "meaningful learning can be achieved by providing the students with a chance to do or discover by themselves" (Bayram, Sökmen \& Gürdal, 1999, p. 45). These "include course instruction content that use teaching materials to achieve goals" (Yanpar, 2007, p. 9). Using these contents, in other words, the concretized models are considered as helping the students to internalize and improve their cognitive skills (Kroll \& Paziotopoulos, 2004). In this study, the analogy teaching model (Glynn et al., 1995) was used. The purpose of this model is "to use thoughts about a known concept (analog/source concept) to learn a new concept (target concept)" (Köseoğlu \& Tümay, 2013, p. 120). This transmission is in the form of clearly revealing the similar aspects of the source and target concepts, in other words, "analogical mapping” (Köseoğlu \& Tümay, 2013, p. 120). This model enables the students to:

- "have different perspectives for the same idea,

- interpret a given concept in more depth,

- understand how they are related to other concepts" (Kesercioğlu et al., 2004, p. 38).

However, "in the use of analogies, there is a danger that students' will map their thoughts incorrectly. In such a situation analogy may lead students to form alternative concepts" (Köseoğlu \& Tümay, 2013, p. 122). In order to prevent this, the mind mapping technique is used. This technique is "not only useful in students' meaningful learning of science concepts, but also helps teachers teach concepts to the students" (Bayram et al., 1997b, p. 80). In this study, analogical mapping was used while designing teaching materials for the subject.

\subsection{Sampling}

The sample of the study was the mathematics textbook for twelfth grade. While deciding on the sample the suggestion by Örnek (2007, p. 77), "studies of the effect of the use of animation method in education on students' creativity in mathematics should be conducted at all levels" was considered.

\subsection{Data Collection Tools}

In the design of the material, the Analogy Teaching Model (Glynn et al., 1995) was used. As for the development of the teaching material, the "This is My Work" project format (MEB, 2012b, p. 24) was taken into consideration.

\subsection{Data Analysis}

In the evaluation of the teaching material designed according to the Analogy Teaching Model (Glynn et al., 1995) and developed in line with the "This is My Work" project format (MEB, 2012b, p. 24), principles 1, 7 and 10 of Yanpar's (2007, pp. 155-159) material development principles were considered:

- "Teaching materials should be simple and understandable.

- Teaching materials should reflect real life as much as possible.

- Materials to be reused over time should be durable and should not be damaged by a single use."

\section{Results}

In this design, the mapping between the similar aspects of the source concept (analog) and the target concept (the continuity of tangent function) are shown in Table 1. 
Table 1. A sample analogy for the continuity of the tangent function

\begin{tabular}{|c|c|c|}
\hline Target Concept & Source Concept (Analog) & Relationship \\
\hline $\begin{array}{l}\text { Tangent function's } \\
(y=\tan x) \text { continuity; }\end{array}$ & Bridge & Continuity of tangent function is likened to a bridge \\
\hline$(-\pi / 2, \pi / 2)$ & Piers of a bridge (in east-west direction) & $\begin{array}{l}\text { The values that tangent function has in the limits } \\
\text { of }-\pi / 2 \text { and } \pi / 2 \text {, are likened to the piers of a bridge in } \\
\text { the east-west direction. }\end{array}$ \\
\hline
\end{tabular}

The conversion of this display into the Analogy Teaching Model took 14 weeks. The studies conducted can be summarized as follows:

$I^{\text {st }}$ Week: The subjects in the mathematics textbook for twelfth graders by the Ministry of National Education were scanned.

$2^{\text {nd }}$ Week: It was determined whether the materials used for the activities in the textbook met the needs of the subject.

$3^{r d}$ Week: This was determined according to the opinions of the 20 students taking the course and 2 education experts conducting the course.

$4^{\text {th }}$ Week: It was determined that the page 68 drawings are made, photos are presented, and a picture is used to illustrate the continuity of tangent function concept/subject.

$5^{\text {th }}$ Week: Whether these drawings, photos and the picture correspond to the material preparation principles of Yanpar (2007: 155-159) was discussed in class.

$6^{\text {th }}$ Week: At the end of this discussion, it was determined that the drawings, photos and the picture conflicts with Yanpar's (2007: 155-159) teaching material preparation principles 1, 7 and 10.

$7^{\text {th }}$ Week: It was decided to compensate for this lack using the Analogy Teaching Model and additionally taking into consideration the "This is My Work" project format and Yanpar's (2007) teaching material preparation principles 1,7 and 10 .

$8^{\text {th }}$ Week: The relevant literature was reviewed. The literature review was conducted to figure out whether any materials had been designed/developed for the continuity of tangent function concept/subject using the Analogy Teaching Model.

$9^{\text {th }}$ Week: It was discussed and decided whether the review of literature was adequate for the subject.

$10^{\text {th }}$ Week: The necessities to be used in the design of the teaching material were brought to the classroom and presented to the students attending the course and field experts, and finally they were decided to be used.

$11^{\text {th }}$ Week: Material design began.

$12^{\text {th }}$ Week: Material design continued.

$13^{\text {th }}$ Week: Material design was finished.

$14^{\text {th }}$ Week: Whether the design met the needs of the subject was evaluated by the students attending the course and field expert teachers.

\subsection{Limitations}

The study is limited to its subject and applications of it. The reason behind this limitation can be found in John Nash's dictum, "There is no justice in society where a good level of mathematics is not known" (T24 Bağımsız Internet Gazetesi, 2012). This expression stresses the importance of mathematics. This is how the famous mathematician, John Nash, reacted after learning that Turkey is the second worst in the world in terms of mathematics. According to him, in such a situation educating children at home without sending them to school would provide better results (T24 Bağımsız İnternet Gazetesi, 2012). This encouraged the researcher to believe that this subject can be covered using this teaching model.

\section{Conclusion and Discussion}

A person alone lives with an unreal perceptional map (Demirel, 2011). Locke, Berkeley and Hume stated that the house of knowledge is built with bricks taken from these maps (Baç, 2007). This house is built as a whole 
according to Gestalt psychologists (Demirel, 2011). Rogers stated that students understand the field by means of their perceptions in the real process of building this house (Demirel, 2011). According to Rogers, a sort of learning method therapy (Demirel, 2011) and cognitive animation methods (Winston, 2003) are used in the construction of meaning. Of these, animation is prominent in design. In this method, the high-level cognitive processes used in design - finding differences, using imagination, questioning, critical thinking, reasoning, etc. - have an important place (MEB, 2006). During this reasoning, it is possible to discover the models in the students' minds by means of their drawings (Demircioğlu et al., 2013). A study conducted using this method showed that memorability was increased by teaching trigonometry with animation techniques (Örnek, 2007). It is important to develop materials that meet learners' needs and increase memorability as described by Taba (1962) and Tyler (1949) (Aydin, 2013b). According to Thomas Aquinas, it is also important that these needs should be met properly. This can be achieved by meeting the needs of the subject as described by Taba (1962) and Tyler (1949). This study aimed to meet the needs of the subject of "the continuity of tangent function" (MEB, 2012a, p. 68), and the Analogy Teaching Model (Glynn et al., 1995) was used to do so.

There is a bridge called "tangent bridge" which is similar to the tangent function in the province of Trabzon of Turkey. If well explored, it will be seen that there are paths and bridges similar to the graph of the tangent function in the World. Mathematics teachers can make contributions to the needs of the subject while taking this topic into consideration, by making exemplifications based on the concrete material developed. The concept of continuity can be related to the way in which the vehicles passing over the bridge proceed without any obstacles. It can also be stressed that in the event of a natural disaster such as an earthquake or landslide, the bridge is damaged, if a situation occurs that would block the flow of traffic, it does not correspond to the definition of continuity of tangential function. In addition to this, topics such as speed, time, slope which is frequently encountered in science and mathematics courses can be discussed among the developed materials to make interdisciplinary associations to ensure the needs of the subject. If such associations are made, the developed "Portable Tangent Bridge" material can be provided as the most important element of education expressed by Brown (1993) and Clement (1993).

At the end of this study, in order to meet the needs of the continuity of tangent function on page 68 of the textbook, "The Portable Tangent Bridge Model" was designed and developed based on the analogy teaching model (Glynn et al., 1995) (Appendix). In the development of this material, unlike the study by Örnek (2007):

- Waste materials such as styrofoam, batteries, thin cables, small lamps, silicon, etc., which cause environmental pollution, were recycled into course materials.

Additionally, the continuity of tangent function's areas of use in daily life was concretized. In other words, it was converted into the Analogy Teaching Model. The literature reports that using concretized models helps students to internalize and improve their cognitive skills (Kroll \& Paziotopoulos, 2004). In this way, "the basis for meaningful learning is set" (Yanpar, 2007, p. 61). "The basis of Gardner's multiple intelligences theory is that there is no single way to learn, and each subject can be learned in more than one way"(Yanpar, 2007, p. 50). There is no single route that this theory follows, and teachers who can figure out the differences between students are very important. "It is again very important that the teachers need to know their students very well and create activities, dynamic environments and teaching materials that refer to different areas as much as possible" (Yanpar, 2007, p. 51). Preparing teaching materials in the analogy format will meet the needs of the subject. In order to meet these needs, teachers' having pedagogic information along with knowledge of the field is also important (Shulman, 1986). In the teaching process in courses, teachers with this knowledge (Shulman, 1987) need to use "models, analogies, examples, presentations and simulations" in order for students to learn better, in other words, to meet the learners' needs (Aydın, 2013b). The Portable Tangent Bridge Model, which was developed to meet the needs of the subject can contribute to the effectiveness of the teaching processes (Shulman, 1987) of the teachers with pedagogic information in addition to the knowledge of the field (Shulman, 1986). This contribution can be made by a qualified teacher with a strong background in the subject (Uyulgan \& Kartal, 2012). In this way, the needs of the subject as stated by Taba (1962) and Tyler (1949) will be met. In other words, the objectives regarding the subject can be determined, and these objectives can be expressed as behaviors. It has been said that these needs will shift to fields such as agriculture, health and communication in the future (Burden, 2007).

Additionally, with the help of this model, the needs of the subjects that will shift to fields such as agriculture, health and communication can be met. The model for meeting the needs of the subject was first developed in this study. This shows that the study of designing and developing the model contributes to the literature.

The latest studies show that students' attitudes towards science are worsening in Europe (e.g., The ROSE project; Jøberg \& Schreiner, 2005); cited in (Bağ \& Savran-Gencer, 2012). These studies say that this is caused by conflicts between students' experiences with, needs from and expectations of the science curriculum and teaching (Osborne 
\& Dillion, 2008).

A recent study found that, in many countries around the world, the obstacle to science education reform is the use of the terminologies of deep-rooted philosophical conflicts without criticism (Dillon, 2009). The attitudes towards mathematics and science can be enhanced with models developed for them, contributing to the riddance of the conflict and criticism of deep-rooted philosophical conflicts' terminologies.

\section{Suggestions}

The model developed in this study can serve as an example towards meeting the needs of the subject described by Taba (1962) and Tyler (1949). Arf described it as meeting the needs of concepts/subjects towards knowledge and its product, technology (Terzioğlu \&Yımaz, 2006).

\section{References}

Altunkaya, B. (2012). Matematik, İnsana "Bence" İle Başlayan Cümleler Kurmayı Öğretir! Ahi Evran Üniversitesi Bilim Kültürve Sanat Dergisi, 3, 40-42.

Atav, E., Erdem, E., Yılmaz, A., \& Gücüm, B. (2004). Enzimler Konusunun Anlamlı Öğrenilmesinde Analojiler Oluşturmanın Etkisi. Hacettepe Üniversitesi Eğitim Fakültesi Dergisi, 27, 21-29.

Aydın, A. (2012). Learning approaches and models adopted in the high school chemistry curricula in several nations. The Journal of Academic Social Science Studies, 5(8), 143-169.

Aydın, A. (2013a). Learner Acquisition and Its Relationship with Constructivist Learner Roles in a Secondary Education Chemistry Curriculum in Québec/Canada. International Education Studies, 6(7), 88-99. https://doi.org/10.5539/ies.v6n7p88

Aydın, A. (2013b). Material Development and Meeting Learner's Need. Educational Research and Reviews, $8(17), 1533-1543$.

Baç, M. (2007). Epistemoloji. In Ahmet Cevizci (Ed.), Felsefe Ansiklopedisi (cilt 5). İstanbul: Babil Yayıncılık.

Bağ, H., \& Savran-Gencer, A. (2012, Haziran). Farklılıklar için fen eğitimi: çok uluslu bir fen eğitimi ve bilimin doğası anketinin geliştirilmesi. X. Ulusal Fen Bilimleri ve Matematik Eğitimi Kongresi, Niğde, Türkiye.

Bayrakçeken, S., \& Çelik, S. (2007). Bilimin Doğası. Retrieved April, 9, 2014, from http://celiksuat.wordpress.com/sunularim/

Bayram, H., Patlı, H., \& Savcı, H. (1998a). Öğrenme Halkası Modeli ve Lise-1 Öğrencilerinin Mantıksal Düşünme Yetenekleri ile Kimya Dersine Karşı Olan Tutumları Arasındaki İlişki. M.Ü. Atatürk Eğitim Fakültesi Eğitim Bilimleri Dergisi, 10, 21-30.

Bayram, H., Patlı, H., \& Savcı, H. (1998b). Fen Öğretiminde Öğrenme Halkası Modeli. M. ̈. Atatürk Eğitim Fakültesi Ĕgitim Bilimleri Dergisi, 10, 31-41.

Bayram, H., Sökmen, N., \& Gürdal, A. (1999). Öğrencilerin Temel Fen Kavramlarını Anlama Düzeylerinin Öğretim Kademesi ile Değişimi ve Öğrencilerin Mantıksal Düşünme Yetenekleri Arasındaki İlişki. M.Ü. Atatürk Ĕ̈itim Fakültesi Ĕgitim Bilimleri Dergisi, 11, 39-48.

Bayram, H., Sökmen, N., \& Savcı, H. (1997a). Temel Fen Kavramlarının Anlaşılma Düzeyinin Saptanması. M.Ü. Atatürk Eğitim Fakültesi Eğitim Bilimleri Dergisi, 9, 89-100.

Bayram, H., Sökmen, N., \& Savcı, H. (1997b). Önbilgi, Mantıksal Düşünme Yeteneği, Laboratuvar ve Kavram Haritası Yöntemlerinin Temel Kimya Kavramlarının Öğretilmesinde Başarıya Etkisi. M.Ü. Atatürk Ĕgitim Fakültesi Eğitim Bilimleri Dergisi, 9, 79-88.

Beydoğan, H. Ö. (2011). Zihin Haritası Destekli Bilişsel Hazırlığın Öğrencilerin Bilgilendirici Yazma Yeterliği Üzerine Etkisi. Ahi Evran Üniversitesi Kırşehir Eğitim Fakültesi Dergisi (KEFAD), 12(4), 1-23.

Bilge Sözleri. (2014, April 16). In Bilge Sözleri. Retrieved April 17, 2014, from http://www.bilgesozleri.com/marcus-aurelius-sözleri.html

Bilgin, İ., \& Geban, Ö. (2001). Benzeşim (Analoji) Yöntemi Kullanarak Lise 2.Sınıf öğrencilerinin Kimyasal Denge Konusundaki Kavram Yanılgılarının Giderilmesi. Hacettepe Üniversitesi Eğitim Fakültesi Dergisi, 20, 26-32.

Brown, D. E. (1993). Refocusing Core Intuitions: A Concretizing Role for Analogy in Conceptual Change. Journal of Research in Science Teaching, 30(10), 1273-1290. https://doi.org/10.1002/tea.3660301009

Burden, J. (2007). Twenty First Century Science: developing a new science curriculum. Science in School, Issue 
$5,74-77$.

Clement, J. (1993). Using Bridging Analogies and Anchoring Intuitions to Deal with Students' Preconceptions in

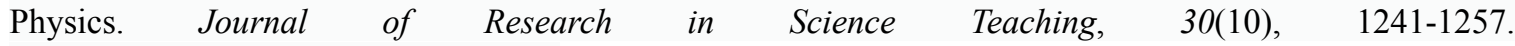
https://doi.org/10.1002/tea.3660301007

Curtis, R. V., \& Reigeluth, C. M. (1984).The use of analogies in written text. Instructional Science, 13(2), 99-117. https://doi.org/10.1007/BF00052380

Dagher, Z. R. (1994). Does the Use of Analogies Contribute to Conceptual Change? Science Education, 78(6), 601-614. https://doi.org/10.1002/sce.3730780605

Dagher, Z. R. (1995). Analysis of Analogies Used by Science Teachers. Journal of Research in Science Teaching, 32(3), 259-270. https://doi.org/10.1002/tea.3660320306

Demircioğlu, H., Vural, S., \& Demircioğlu, G. (2013). Üstün yetenekli öğrencilerin zihinsel modelleri: Maddenin tanecikli yapısı. Eğitim Bilimleri Dergisi. Cilt-Sayı, 38, 65-84.

Demirel, Ö. (2011). Kuramdan Uygulamaya Eğitimde Program Geliştirme (17th ed.). Ankara: Pegem Akademi.

Dillon, J. (2009). On Scientific Literacy and Curriculum Reform. International Journal of Environmental \& Science Education, 4(3), 201-213.

Duit, R. (1991). On the Role of Analogies and Metaphors in Learning Science. Science Education, 75(6), 649-672. https://doi.org/10.1002/sce.3730750606

Fook, C. Y., \& Sidhu, G. K. (2010).Authentic Assessment and Pedagogical Strategies in Higher Education. Malaysia Journal of Social Sciences, 6(2), 153-161. https://doi.org/10.3844/jssp.2010.153.161

Forum Memurlar Net. (2014, April 25). In Forum Memurlar Net. Retrieved April 26, 2014, from http://forum.memurlar.net/konu/655737/

Gasco, J., Villarroel, J. D., \& Zuazagoitia, D. (2014). Different Procedures for Solving Mathematical Word Problems in High School. International Education Studies, 7(7), 77-84. https://doi.org/10.5539/ies.v7n7p77

Genç, H., Genel, Y., \& Küçük, M. M. (2001, Eylül). Kimya Öğretiminde Teorik Olarak Öğretilen bazı Kavramların Deneyle Öğretilmesi Sonucu Anlaşılıp-anlaşılmadığının Belirlenmesi, XV.Ulusal Kimya Kongresi, Boğaziçi Üniversitesi, İstanbul, Türkiye.

Glynn, S. M., \& Takahashi, T. (1998). Learning from analogy-enhanced science text. Journal of Research in Science Teaching, 35(10), 1129-1149. https://doi.org/10.1002/(SICI)1098-2736(199812)35:10<1129::AID-TEA5>3.0.CO;2-2

Glynn, S. M., Duit, R., \& Thiele, R. B. (1995).Teaching science with analogies: A strategy for constructing knowledge. In S. M. Glynn, \& R. Duit (Eds.), Learning Science in the Schools: Research Reforming Practice (pp. 247-273). Mahwah, NJ: Erlbaum.

Güçlü, M. (2013). Boşluk sergisi Brüksel'de! Retrieved February 7, 2014, from http://sanat.milliyet.com.tr/-bosluk-sergisi-bruksel-de-/plastiksanatlar/haberdetay/04.03.2013/1676095/defa ult.htm

Güran, Y. (2011). Eğitim!-Üniversitelerimiz Bağlaminda?!... Retrieved February 7, 2014, from http://www.yalcinguran.com/2011/02/egitim-universitelerimiz-baglaminda/

Hardy, G. H. (1994). Bir Matematikçinin Savunması (Çeviri, Nermin Arık). Ankara: Pelin Ofset.

Kaya, Z., Tüfekçi, S., \& Bilasa, P. (2010). Teknoloji ve tasarım eğitiminde yapılandırmacılık uygulamaları. Eğitime Baklş, 6(17), 20-29.

Keller, J.M. (1983). Motivational Design of Instruction. In C. M. Reigeluth (Eds.), Instructional Design Theories and Models: An Overview of Their Current Status. Hillsdale, NJ: Lawrence Erlbaum Associates.

Kesercioğlu, T., Yılmaz, H., Huyugüzel Çavaş, P., \& Çavaş, B. (2004). İlköğretim Fen Bilgisi Öğretiminde Analojilerin Kullanımı: “Örnek Uygulamalar”. Ĕge Eğitim Dergisi, 5, 35-44.

King, J. P. (2003). Matematik Sanatı (Çev. Nermin Arık). Ankara: Tubitak Yayınları.

Köseoğlu, F., \& Tümay, H. (2013). Bilim Eğitiminde Yapılandırıcı Paradiğma. Ankara: Pegem Akademi.

Kosmoss.Net. (2014, April 25). In Kosmoss.Net. Retrieved April 26, 2014, from http://www.kosmoss.net/?pnum=148\&pt=Deneyim\%20\%C4\%B0le\%20\%C4\%B0lgili\%20S\%C3\%B6zler 
Kroll, M., \& Paziotopoulos, A. (2004). Hooked on thinking. International Reading Association, 57(7), 672-677.

Küçük, M. M., \& Saka, C. (2001, Eylül). Vandaki Liselerede Kimya Öğretiminde Anlaşılmayan Bazı Kavramların Belirlenmesi, XV. Ulusal Kimya Kongresi, Boğaziçi Üniversitesi, İstanbul, Türkiye.

Küçük, M. M., Yetim, M., Saka, C., \& Genel, Y. (2002, Eylül). Kimya Eğitim ve Öğretiminde Uygulanan Öğretim Yöntemleri Etkin Kavram Öğretimi Arasındaki İlişkinin İncelenmesi, $V$. Ulusal Fen Bilimleri ve Matematik Eğitimi Kongresi, ODTÜ Kültür ve Kongre Merkezi, Ankara, Türkiye.

Lawson, A. E. (1993). The Importance of Analogy: A Prelude to the Special Issue. Journal of Research in Science Teaching, 30(10), 1213-1214. https://doi.org/10.1002/tea.3660301004

MEB. (2004). Illköğretim ve ortaöğretim düzeyinde ögretim programları tasarımı projesi. Yalova: Hizmet İçi Eğitim Seminerleri.

MEB. (2006). İlköğretim Teknoloji ve Tasarım Dersi Öğretim Programı ve Klavuzu (6, 7 ve 8 Sinıflar). Ankara: Talim ve Terbiye Kurulu Başkanlı̆̆ı.

MEB. (2012a). Ortaöğretim Matematik 12. Sinıf Ders Kitabı (5. Baskı). Ankara: Milli Eğitim Bakanlığı Yayınları.

MEB. (2012b). Bu Benim Eserim VIII. İlköğretim Öğrencilerine Yönelik Matematik ve Fen Bilimleri Proje Çalışması Uygulama Kılavuzu. Ankara: Temel Eğitim Genel Müdürlüğü. Retrieved September 3, 2013, from http://tegm.meb.gov.tr/meb_iys_dosyalar/2012_11/02025846_25015839_20122013bbeuygkilavuzu. pdf

Meşhur Sözler. (2013, November 12). In Meşhur Sözler. Retrieved November 13, 2013, from http://www.meshursozler.com/oku/8723-yaslanarak-degil-yasayarak-tecrube-kazanilir-zaman-insanlari-degi 1-armutlari-olgunlastirir.html

Morgil, İ., Erdem, E., \& Yılmaz, A. (2003). Kimya eğitiminde kavram yanılgıları. Hacettepe Üniversitesi Ĕgitim Fakültesi Dergisi, 25, 246-255.

My Yoga Online. (2014, May 01). In My Yoga Online. Retrieved May 2, 2014, from https://www.facebook.com/myyogaonline/photos/a.77321572983.80942.32231322983/1015207646941798 $4 /$ type $=1 \&$ theater

Örnek, S. (2007). Trigonometrik Kavramların Canlandırma Yöntemiyle Öğrenilmesinin Öğrencilerin Matematik Başarısına Etkisi (Basılmamış Yüksek Lisans Tezi). Marmara Üniversitesi, İstanbul, Türkiye.

Osborne, J., \& Dillon, J. (2008). Science education in Europe: Critical reflections. King's College London: The Nuffield Foundation.

Özçelik, D. A. (1988). Prof. Dr. H. Selahattin Ertürk'ün Egitime Bakış Açısı Düşünce ve Uygulamalarda Yeni Bir Çagın Başlangıcı Olmuştur. Hacettepe Üniversitesi Eğitim Fakültesi Dergisi, 3, 31-34.

Paton, R. C. (1996). On an Apparently Simple Modelling Problem in Biology. International Journal of Science Education, 18(1), 55-64. https://doi.org/10.1080/0950069960180105

Pittman, K. M. (1999). Student generated analogies: Another way of knowing? Journal of Research in Science Teaching, 36(1), 1-22. https://doi.org/10.1002/(SICI)1098-2736(199901)36:1<1::AID-TEA2>3.0.CO;2-2

Ressamlar. (2014, May 01). In Ressamlar. Retrieved May 2, 2014, from http://www.ressamlar.gen.tr/pablo-picasso-sozleri/

Sarıtaş, D., \& Tufan, Y. (2012, Haziran). Öğrencilerin kimya bilgilerinin kimyasal semiyotik; sentaks ve semantic açısından incelenmesi. X. Ulusal Fen Bilimleri ve Matematik Eğitimi Kongresi, Niğde, Türkiye.

Say, C. (2005). Gödel'in Eksiklik Teoremi. Matematik Dünyası, 14(4), 67-71.

Saygıl1, S. (2008). Analojiile Öğretim Yönteminin 9. Sinıf Öğrencilerinin Matematik Başarılarına ve Yaratıcı Düşünmelerine Etkisi (YayınlanmamışYüksek Lisans Tezi). Çanakkale Onsekiz Mart Üniversitesi, Çanakkale, Türkiye.

Schnackenberg, H. L., \& Still III, G. (2014). Teacher Preparation Programs and Technology Integration: Best Practices For Curriculum Design. International Journal of Education and Practice, 2(7), 147-158. https://doi.org/10.18488/journal.61/2014.2.7/61.7.147.158

Shulman, L. S. (1986). Those who understand: Knowledge growth in teaching. Educational Researcher, 15(2), 4-14. https://doi.org/10.3102/0013189X015002004 
Shulman, L. S. (1987). Knowledge and teaching: Foundations of the new reform. Harward Educational Review, 57, 1-23. https://doi.org/10.17763/haer.57.1.j463w79r56455411

Stepich, D. A., \& Newby, T. J. (1988). Analogizing as an Instructional Strategy. Performance and Improvement, 27(9), 21-23. https://doi.org/10.1002/pfi.4170270911

Sturges, P. (2014). The brain at the centre of the information universe: lessons from popular neuroscience. Libellarium, VII(1), 3 - 15.

T24 Bağımsız İnternet Gazetesi. (2012, June 22). In T24 Bağımsız İnternet Gazetesi. Retrieved June 23, 2014, from http://t24.com.tr/haber/nobelli-matematikci-john-nash-iyi-matematik-bilmeyen-toplumlarda-adaletyoktur,209127

Taba, H. (1962). Curriculum development: Theory and practice (Brace \& World). New York: Harcourt.

Terzioğlu, T., \& Yılmaz, A. (2006). Cahit Arf / Anlamak Tutkunu Bir Matematikçi. Ankara: Türkiye Bilimler Akademisi (TÜBA) Yayınları.

Thiele, R. B., \& Treagust, D. F. (1994). An Interpretive Examination of High School Chemistry Teachers' Analogical Explanations. Journal of Research in Science Teaching, 31(3), 227-242. https://doi.org/10.1002/tea.3660310304

Tolman, E. C. (1922). A new formula for behaviorism. Psychological Review, 29(1), 44-53. https://doi.org/10.1037/h0070289

Tolman, E. C. (1948). Cognitive maps in rats and men. Psychological Review, 55(4), 189-208. https://doi.org/10.1037/h0061626

Tyler, R.W. (1949). Basic Principles of Curriculum and Instruction. IL: The University of Chicago.

Uyulgan, M. A., \& Kartal, M. (2012, Haziran). Kimya alan bilgisi başarı testinin geliştirilmesi. X. Ulusal Fen Bilimleri ve Matematik Ĕgitimi Kongresi, Niğde,Türkiye.

Vosniadou, S. (1989). Analogical reasoning as a mechanism in knowledge acquisition: A developmental perspective. In S. Vosniadou, \& A. Ortony (Eds.), Similarity and analogical reasoning (pp. 413-437). Cambridge: Cambridge University Press. https://doi.org/10.1017/CBO9780511529863.020

Westfall, R. S. (1994). Modern Bilimin Oluşumu (Çeviri, İsmail Hakkı Duru). Ankara: Türk Matbaacılık Sanayi A.Ş.

Winston, R. (2003). The human mind and how to make the most of it. London: Bantam Books. Retrieved November 22, 2017, from https://www.amazon.com/Human-Mind-How-Make-Most/dp/0593052102

Yalçın, Ş. (2014). Kant'ta Matematiğin Felsefi Temelleri-1. Retrieved February 7, 2014, from http://eulergauss.blogcu.com/kant-ta-matematigin-felsefi-temelleri-1/9027141

Yanpar, T. (2007). Öğretim Teknolojileri Materyal Tasarımı (8nd ed.). Ankara: Anı Yayıncılık.

Yeniçeri, Z. (2003). Edward Chace Tolman ve bilişsel davranışçılık. PiVOLKA, 2(10), 14-16. Retrieved from http://www.baskent.edu.tr/ Zuyen/articles/tolman.html

Yiğit, B. (2013). KPSS Konu Anlatımlı Soru Bankası. Eğitimci Öğretmen Dergisi, Sayı: 18, Eki-18.

Yıldırım, Ö. (2009). Копи: Sokrat (Sokrates). Retrieved February 7, 2014, from http://www.estanbul.com/sokrat-sokrates-25071.html 


\section{Appendix}

\section{The Portable Tangent Bridge Model}

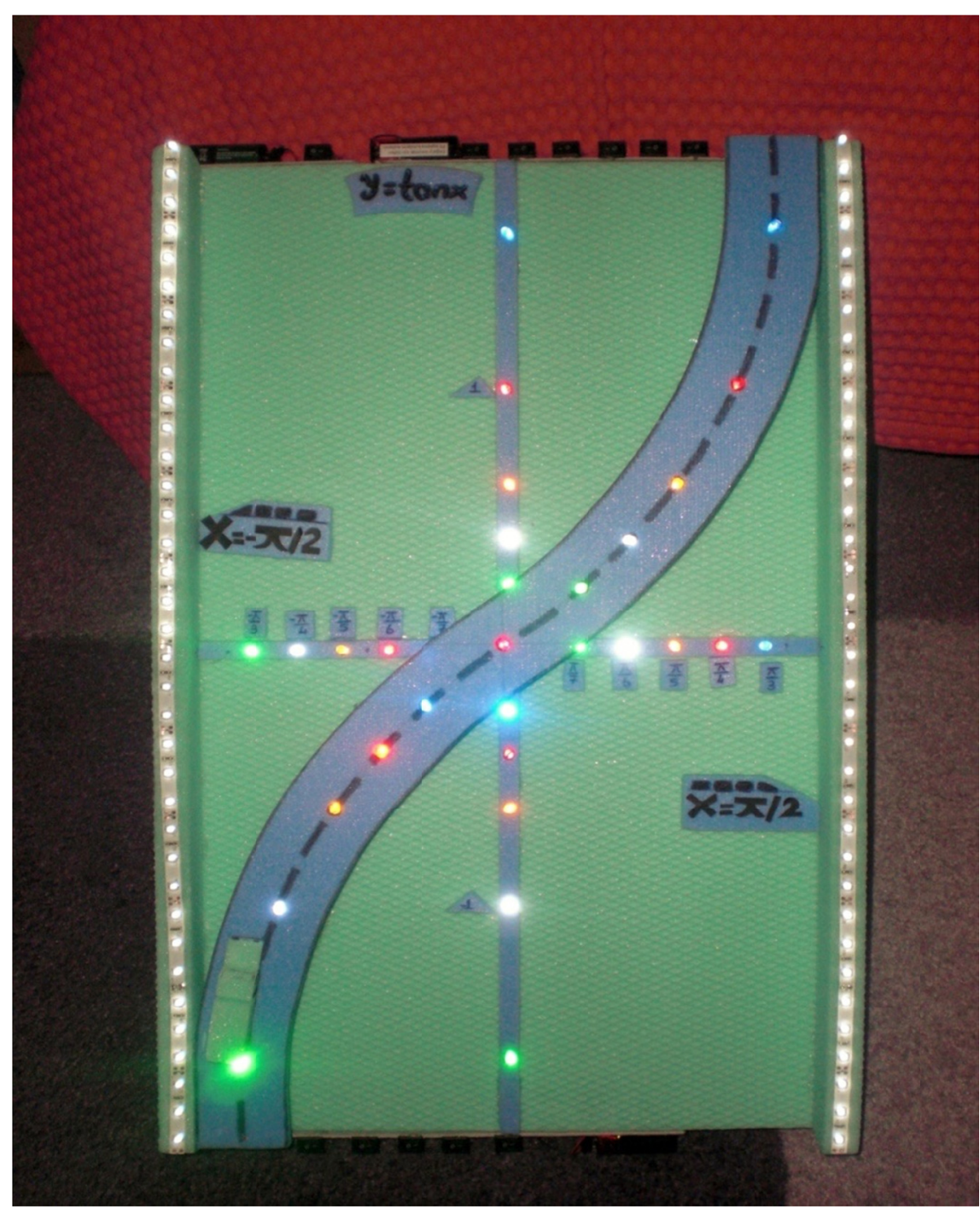

\section{Copyrights}

Copyright for this article is retained by the author(s), with first publication rights granted to the journal.

This is an open-access article distributed under the terms and conditions of the Creative Commons Attribution license (http://creativecommons.org/licenses/by/4.0/). 